Porma Eka Lestari, Nasifiudin, Sani Insan Mutiamadi

Penerapan Model Pembelajaran Learning Cycle 5E untuk Meninghathan Motivasi

Belajar Siswa pada Mata Pelajaran Sejarah Kebudayaan Islam (SKI)

\title{
PENERAPAN MODEL PEMBELAJARAN LEARNING CYCLE 5E UNTUK MENINGKATKAN MOTIVASI BELAJAR SISWA PADA MATA PELAJARAN SEJARAH KEBUDAYAAN ISLAM (SKI)
}

\author{
Norma Eka Lestari, Nasihudin, Sani Insan Muhamadi \\ UIN Sunan Gunung Djati Bandung \\ lestarinormaeka@gmail.com,nspono20@gmail.com
}

\begin{abstract}
Abstrak
Penelitian ini bertujuan untuk mengetahui proses penerapan model pembelajaran Learning Cycle $5 e$ pada mata pelajaran SKI, mengetahui peningkatan motivasi belajar siswa pada mata pelajaran SKI di kelas V MI Plus Al Luqman. Untuk mencapai tujuan tersebut, penelitian ini menggunakan metode penelitian tindakan kelas (PTK) yang terdiri dari empat tahapan yaitu perencanaan, pelaksanaan, observasi dan refleksi. Pendekatan yang digunakan yaitu pendekatan kualitatif dan kuantitatif. Teknik pengumpulan data dilakukan melalui wawancara dengan guru kelas, angket untuk mengetahui pengukuran motivasi belajar siswa dan melalui instrument lembar observasi aktivitas dengan subjek penelitian yaitu siswa kelas V MI Plus Al Luqman Garut dengan jumlah siswa sebanyak 19 orang yang terdiri dari 11 siswa laki-laki dan 8 siswa perempuan. Berdasarkan hasil penelitian, bahwa motivasi belajar siswa dengan menggunakan model pembelajaran Learning Cycle $5 e$ pada mata pelajaran SKI mengalami peningkatan. Hal ini berdasarkan hasil sebaran angket motivasi belajar yang diberikan pada siklus I dan siklus II diperoleh rata-rata sebesar $64 \%$ dan $86 \%$ serta presentase aktivitas belajar siswa diperoleh $76,32 \%$ dan $87,37 \%$. Sehingga dapat disimpulkan bahwa model pembelajaran Learning Cycle $5 e$ dapat meningkatkan motivasi belajar siswa pada mata pelajaran SKI di kelas V MI Plus Al Luqman Garut.
\end{abstract}

Kata Kunci: Learning Cycle 5e, Model Pembelajaran, Motivasi Belajar

\begin{abstract}
This study aims to determine the process of implementing the Learning Cycle 5e learning model in the SKI subject, to determine the increase in student motivation in the SKI subject in class V MI Plus Al Luqman. To achieve this goal, this study uses a classroom action research (CAR) method which consists of four stages, namely planning, implementing, observing and reflecting. The approach used is qualitative and quantitative approaches. Data collection techniques were carried out through interviews with class teachers, questionnaires to determine the measurement of student learning motivation and through the activity observation sheet instrument with the research subjects, namely students of class V MI Plus Al
\end{abstract}


Luqman Garut with 19 students consisting of 11 male students and 8 female students. Based on the results of the study, that the learning motivation of students using the Learning Cycle 5e learning model in the SKI subject has increased. This is based on the results of the distribution of the learning motivation questionnaire given in the first cycle and the second cycle obtained an average of $64 \%$ and $86 \%$ and the percentage of student learning activities obtained $76.32 \%$ and $87.37 \%$. So it can be concluded that the Learning Cycle 5e learning model can increase student learning motivation in the SKI subject in class V MI Plus Al Luqman Garut.

Keywords: Learning Cycle 5e, Learning Models, Learning Motivation

\section{PENDAHULUAN}

Sejarah adalah cerita lampau ataupun suatu akar awal mula sumber kejadian yang di ingat sepanjang masa oleh setiap orang. Sejarah Kebudayaan Islam yakni sebuah perangkat kurikulum pendidikan Islam. Dalam sejarah memiliki materi yang bersifat masuk akal seperti urutan kronologis cerita sejarah yang memiliki makna sebenarnya di masa lampau (Mansyah, 2016). Sejarah Kebudayaan Islam yaitu cerita mengenai perjalanan hidup seorang muslim dari perpindahan waktu dalam kegiatan agama, perekonomian, sosial dan berakhlak serta dalam mengembangkan sistem kehidupannya yang dilandasi oleh akidah (Salim, 2017). Dari penjelasan tersebut bahwasannya Sejarah Kebudayaan Islam merupakan kisah lampau yang mempunyai asal muasal kronologis fakta-fakta tertentu. Di zaman modern ini sejarah begitu penting untuk dipahami. Salah satunya pembelajaran sejarah di Madrasah Ibtidaiyah yaitu Sejarah Kebudayaan Islam.

Sejarah Kebudayaan Islam adalah mata pelajaran yang penting dipelajari oleh siswa di lembaga pendidikan islam disamping mata pelajaran lain yaitu Al-Quran Hadits, Fiqih dan Akidah Akhlak. Aspek Sejarah Kebudayaan Islam menunjukkan pemberian hikmah yang dapat diambil dalam kehidupan sehari-hari dari peristiwa sejarah Islam yang telah terjadi, menyantuni para tokoh mulia dan mengaplikasikannya dengan fenomena dalam berbagai bidang dalam mengembangkan peradaban yang Islami. Sejarah Kebudayaan Islam di Madrasah Ibtidaiyah merupakan salah satu mata pelajaran yang menelaah tentang asal usul, perkembangan, peranan kebudayaan/peradaban Islam dan para tokoh yang berprestasi dalam sejarah Islam pada masa lampau, mulai dari sejarah masyarakat Arab pra-Islam, sejarah kelahiran dan kerasulan Nabi Muhammad SAW, sampai dengan masa Khulafaurrasyidin. Secara keseluruhan, mata pelajaran SKI memiliki peranan penting dalam memberikan arahan serta motivasi kepada peserta didik untuk mengenal, 


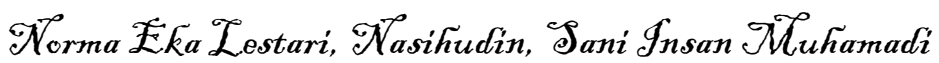

Penerapar Model Penbeligiaran Learning Cycle SE urtul Meninglattar Motivasi

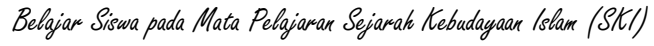

memahami, menghayati Sejarah Kebudayaan Islam, yang mengandung nilai-nilai baik yang dapat digunakan untuk melatih kecerdasan, membentuk sikap, watak, dan kepribadian peserta didik (Salim 2017).

Berdasarkan hasil studi pendahuluan di MI Plus Al Luqman Garut di kelas V dengan pemberian angket diperoleh skor rata-rata hasil angket yaitu sebesar 26 dari skor maksimal 80. Purwanto (2009) memaparkan bahwa hasil tersebut jika dilihat dari kriteria keberhasilan tindakan bahwa masih banyak siswa memiliki motivasi belajar yang kurang pada mata pelajaran SKI. Begitupun wawancara dengan guru kelas diperoleh gambaran tentang pembelajaran SKI, yaitu guru masih kesulitan dalam menyampaikan materi, merencanakan dan melaksanakan pembelajaran dengan metode yang tepat. Proses pembelajaran SKI masih dominan menggunakan metode ceramah begitupun dengan kondisi pembelajaran tidak terpusat pada siswa karena semua kegiatan didominasi oleh guru. Siswa mempunya anggapan bahwa metode ceramah bahwasannya pelajaran sejarah adalah pelajaran menghafal yang membosankan. Anggapan ini sangat mempengaruhi terhadap motivasi belajar siswa. Dari permasalahan tersebut diperlukannya penerapan model pembelajaran yang mampu meningkatkan motivasi belajar siswa dalam pelajaran Sejarah Kebudayaan Islam.

Menurut (Salahudin, 2015) model atau metode pembelajaran adalah suatu usaha untuk menyampaikan pembelajaran dengan interaksi edukatif, karena metode pembelajaran adalah sebuah usaha untuk menghubungkan antara guru dan siswa pada saat proses pembelajaran berlangsung. Terdapat beberapa metode yang bisa merubah suasana belajar yang tidak menjenuhkan bagi siwa. Salah satunya adalah menerapkan model pembelajaran Learning Cycle 5e yaitu model pembelajaran yang mempunyai tahapantahapan kegiatan yang disusun dengan sistematis sehingga siswa mampu memahami tujuan pembelajaran yang harus dicapai secara aktif. Dalam sebuah penelitian menurut (Dwi Aprilia Astupura, 2016) model pembelajaran Learning Cycle 5e mampu meningkatkan semangat motivasi belajar karena siswa berperan aktif ketika belajar sehingga pembelajaran menjadi lebih bermakna. Ciri khas model pembelajaran Learning Cycle 5e yaitu semua siswa belajar materi pembelajaran yang telah disiapkan oleh guru. Lalu materi yang telah dipelajari di diskusikan dengan kelompok masing-masing untuk di pecahkan oleh semua anggota, semua anggota kelompok bersama-sama menyampaikan kepada semua siswa atas hasil yang telah di diskusikannya.

Adapun langkah -langkah dalam model pembelajaran Learning Cycle 5e menurut Piaget (Shoimin, 2014) mengemukakan langkah-langkah model Learning Cycle 5e yaitu:

1. Engagement (Undangan)

Tahap ini guru mengkondisikan siswa agar terkondisikan dalam mencapai fase selanjutnya bertujuan dengan mengeksplorasi pengetahuan awal dan ide-ide mereka serta mengetahui kemungkinan terjadinya miskonsepsi pada pembelajaran 


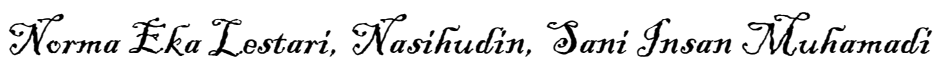

Penerapan Model Pembelajaran Learning Cycle 5E untuk Meninghathan Motivasi Belajar Siswa pada Mata Pelajaran Sejarah Kebudayaan Islam (SKI)

sebelumnya.pada tahap ini siswa diajak membuat perkiraan-perkiraan tentang fenomena yang akan dipelajari dan dibuktikan pada tahap eksplorasi.

2. Exploration (Eksplorasi)

Tahap ini siswa diberikan kesempatan untuk bekerja sama dalam kelompok-kelompok kecil tanpa pengajaran langsung dari guru untuk menguji perkiraan, melakukan dan mencatat pengamatan serta ide-ide, melalui kegiatan-kegiatan seperti praktikum dan telaah literatur.

3. Explanation (Penjelasan)

Tahap ini guru membing siswa dalam menjelaskan pemahamannya dengan kalimat sendiri, meminta bukti dan pembenaran dari penjelasan mereka dan dapat mengarahkan kegiatan diskusi. Pada tahap ini siswa menemukan istilah-istilah dari konsep yang dipelajari.

4. Elaboration (Pengembangan)

Tahap ini siswa mengembangkan konsep dan keterampilan dalam situasi baru melalui kegiatan-kegiatan seperti praktikum lanjutan dan Problem Solving.

5. Evaluation ( Evaluasi)

Pada tahap ini guru menilai dalam proses pembelajaran sudah berjalan dengan baik atau belum, dengan memberikan tes untuk mengukur kemampuan siswa setelah menerima materi pelajaran.

\section{METODE PENELITIAN}

Metode penelitian yang digunakan yaitu Penelitian Tindakan Kelas (PTK) sebanyak 2 siklus yang terdiri dari tahap perencanaan, pelaksanaan, observasi dan refleksi. Dengan pendekatan penelitian menggunakan pendekatan kualitatif dan kuantitatif, data kualitatif merpakan data yang diperoleh dar ideskripsi lembar observasi yang digunakan untuk memberikan gambaran proses pembelajaran SKI melalui penerapan model pembelajaran Learning Cycle $5 e$ yang meliputi aktivitas siswa dan guru. Sedangkan data kuantitatif yaitu data yang berupa angka-angka dan bertujuan untuk memperoleh informasi mengenai data penerapan model pembelajaran Learning Cycle 5e melalui hasil angket dan format lembar observasi. Sumber data dalam penelitian meliputi sumber data primer dan sekunder. Sumber data primer diperoleh dari siswa kelas V MI plus Al Luqman Garut pada tahun ajaran 2019/2020 dengan jumlah siswa sebanyak 19 orang yang terdiri dari 11 siswa laki-laki dan 8 siswa perempuan. Sedangkan data sekunder diperoleh dari dari guru wali kelas V MI Plus Al Luqman.

Teknik pengumpulan data menggunakan pada penelitian ini menggunakan observasi dan angket. observasi menurut (Susilawati, 2013) ialah peneliti melakukan objek penelitian secara langsung untuk melihat dari dekat kegiatan yang dilakukannya. Sedangkan menurut (Dimyati, 2002) observasi adalah sebuah cara yang dilakukan dengan 


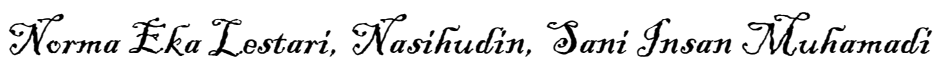

Penerapan Model Pembelajaran Learning Cycle SE untule Meninghathan Motivasi Belajar Siswa pada Mata Pelajaran Sejarah Kebudayaan Islam (SKI)

diadakannya pengamatan secara teliti dan sistematis terhadap apa yang sedang dijadikan objek pengamatan. Observasi dalam penelitian ini terdiri dari observasi aktivitas guru dan aktivitas siswa dalam pembelajaran. Observasi guru memiliki aspek keterlaksanaan kegiatan pembelajaran, observasi siswa terkait aspek kegiatan yang muncul dari siswa setiap fase model pembelajaran Learning Cycle 5e. begitupun dengan lembar observasi penelitian ini berupa ceklis yang digunakan observer disesuaikan sesuai keadaan ketika penelitian berlangsung serta dengan deskripsi pada catatan lapangan.Observasi ini dilakukan untuk mengetahui aktivitas guru dan siswa selama proses pembelajaran berlangsung, sehingga peneliti dapat mengetahui kesesuaiannya dengan RPP yang sudah dibuat sebelumnya serta mampu mengetahui hasil dan dampak dari tindakan pembelajaran tersebut baik dalam berupa respon siswa ketika proses pembelajar maupun perkembangan yang diharapkan. Sedangkan angket (Sugiyono, 2015) menjelaskan bahwa angket yaitu seperangkat pertnyataan yang diberikan oleh peneliti kepada responden untuk mengumpulkan data. Penelitian ini menggunakan angket bagaimana motivasi belajar siswa terhadap mata pelajaran Sejarah Kebudayaan Islam. Kuesioner yang digunakan oleh peneliti yaituinstrumen kuesioner yang terdiri atas pernyataan positif dan pernyataan negative. Begitupun jenis yang kuesioner yang digunakan yaitu menggunakan skala Likert. Pernyataan-pernyataan yang alternatif jawabannya dinyatakan dalam bentuk "SS = Sangat Setuju, S = Setuju, TS = Tidak Setuju, STS= Sangat Tidak Setuju".

\section{HASIL PENELITIAN DAN PEMBAHASAN}

Penelitian ini dilakukan di sekolah MI Plus Al Luqman Garut, dimulai pada tanggal 20 September 2019 dan termasuk studi pendahuluan sekaligus tes awal untuk mengetahui kemampuan siswa yang dirasa masih rendah. Penelitian ini dilakukan dalam rangka memperbaiki kualitas pembelajaran, aktivitas belajar siswa, dengan indicator motivasi belajar siswa pada mata pelajaran SKI dengan menggunakan model pembelajaran Learning Cycle 5e.

1. Proses penerapan model pembelajaran Learning Cycle 5e pada mata pelajaran SKI di kelas V MI Plus Al Luqman Garut

Kegiatan proses belajar siswa dengan menerapkan model pembelajaran Learning Cycle $5 e$ pada setiap siklusnya berjalan dengan baik. Berdasarkan data yang telah dianalisis, aktivitas mengajar guru (peneliti) dan aktivitas belajar siswa mengalami peningkatan pada setiap siklusnya. Peningkatan nilai rata-rata aktivitas guru dan siswa pada setiap siklus dapat digambarkan pada tabel berikut ini : 


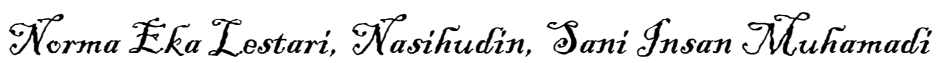

Penerapan Model Pembelajaran Learning Cycle SE untule Meninghathan Motivasi Belajar Siswa pada Mata Pelajaran Sejarah Kebudayaan Islam (SKI)

Tabel 1. Peningkatan Aktivitas Guru dan Siswa Setiap Tindakan

\begin{tabular}{|c|c|c|}
\hline $\begin{array}{c}\text { Data Aktivitas } \\
\text { Pertindakan }\end{array}$ & $\begin{array}{c}\text { Nilai Rata- } \\
\text { Rata Aktivitas } \\
\text { Guru }\end{array}$ & $\begin{array}{c}\text { Nilai Rata-Rata } \\
\text { Aktivitas Siswa }\end{array}$ \\
\hline Siklus I Tindakan 1 & $75 \%$ & $72,28 \%$ \\
\hline Siklus I Tindakan 2 & $85 \%$ & $78,60 \%$ \\
\hline Siklus II Tindakan 1 & $95 \%$ & $85,96 \%$ \\
\hline Siklus II Tindakan 2 & $95 \%$ & $88,77 \%$ \\
\hline
\end{tabular}

Berdasarkan tabel 1 dapat diketahui bahwa aktivitas guru pada setiap siklus I mengalami peningkatan yaitu pada tindakan pertama memperoleh hasil rata-rata $75 \%$ dan pada tindakan kedua memperoleh hasil rata-rata $85 \%$. Hal ini berarti mampu memperbaiki kekurangan-kekurangan yang dilakukan ketika proses pembelajaran pada kegiatan yang dilakukan oleh siswa. Dari hasil analisis data aktivitas belajar mengajar guru dan siswa maka diperoleh bahwa hasil aktivitas belajar mengajar guru dan siswa mengalami peningkatan dari setiap tindakan dan termasuk dalam kriteria sangat baik.

Motivasi belajar sangat dibutuhkan dalam proses pembelajaran karena dengan meningkatnya aktivitas belajar maka akan memengaruhi dalam motivasi belajar siswa. Mata pelajaran SKI biasanya hanya disajikan dalam bentuk teks narasi yang mendominasi sehingga siswa merasa jenuh jika hanya disajikan dalam sebuah teks saja namun pada proses pembelajaran materi usaha Rasul dalam membina masyarakat Madinah di berbagai bidang, siswa terlihat aktif dan antusias, menimbulkan rasa penasaran karena melalui model pembelajaran Learning Cycle 5e ini siswa bukan hanya mendengarkan ceramah dari guru saja tetapi siswa belajar materi yang telah dipersiapkan oleh gruru lalu hasil belajar individual tersebut di diskusikan dengan kelompok masing-masing dan semua anggota kelompok bertanggung jawab bersama-sama atas hasil yang telah di diskusikannya (Shoimin, 2014) dengan menggunakan media kartu domino sejarah, siswa memahami gambaran sejarah Rasul dalam membangun masyarakat Madinah. Proses pembelajaran Learning Cycle melalui 5 tahapan yaitu engagement, exploration, explanation, elaboration dan evaluation.

Pada proses kegiatan pembelajaran menggunakan model pembelajaran Learning Cycle 5e diawali dengan tahap engagement (pendahuluan) yaitu pada tahap awal pembelajaran guru mengondisikan siswa untuk siap mengikuti kegiatan pembelajaran, dalam fase ini minat dan rasa ingin tahu siswa berusaha dibangkitkan. Dengan 


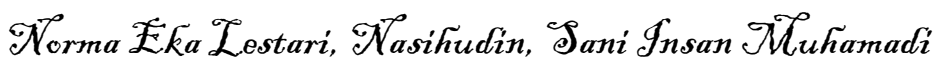

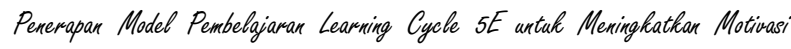

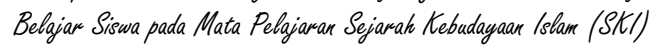

mengondisikan siswa diawal pembelajaran, materi yang akan guru disampaikan akan mudah untuk diterima oleh sisw (Istarani, 2011).

Tahap selanjutnya yaitu exploration (penjelasan) yaitu siswa berdiskusi dengan kelompoknya masing-masing tanpa pengajaran langsung dari guru untuk membuktikannya sendiri (Shoimin 2014). Pada tahap ini siswa mengurutkan sejarah Rasul dalam membina masyarakat Madinah secara benar dan runtut melalui media kartu domino sejarah dalam LKPD yang telah diperisapkan sebelumnya, guru hanya mengawasi dan menjadi fasilitator saja bagi siswa-siswinya.

Tahap explanation (penjelasan) siswa mempresentasikan hasil diskusi bersama kelompoknya di depan kelas, siswa menjelaskannya menggunakan kalimat mereka sendiri serta mengarahkan kegiatan diskusi. Selain itu guru membimbing agar berjalannya diskusi sedangkan siswa yang lainnya mendengarkan, menyanggah jika ada jawabab yang kurang tepat atau ingin berpendapat. Setelah siswa selesai presentase guru memberikan applause sebagai rasa terimakasih atau penghargaan terhadap atas apa yang telah disampaikan. Pada tahap elaboration (pengembangan), guru meminta siswa untuk mengaplikasikan, mengambil hikmah, memberikan contoh positif dari sejarah Rasul yang telah disampaikan oleh kelompok masing-masing. Tahap terakhir yaitu evaluation (evaluasi) yaitu guru memberikan berupa soal apakah pembe;ajaran telah berlangsung baik.

Model pembelajaran Learning Cycle 5e sesuai dengan teori belajar Piaget bahwa belajar yaitu mengembangkan aspek kognitif yaitu meliputi struktur, isi dan fungsi. Struktur yaitu kemampuan intelektual tinggi yang dimiliki oleh manusia untuk memecahkan masalah, isi yaitu respon yang dimiliki secara khas yang dimiliki oleh individu dalam memecahkan masalah sedangkan fungsi yaitu perkembangan intelektual yang meliputi adaptasi dan organisasi (Arikunto 2015). Dengan suasana yang menyenangkan maka siswa akan lebih aktif untuk belajar dan lebih memudahkan memahami materi sejarah serta mengurangi rasa kejenuhan dalam mata pelajaran sejarah. Dengan demikian dapat disimpulkan bahwa model pembelajaran Learning Cycle 5e dalam proses pembelajaran mata pelajaran SKI dapat meningkatkan aktivitas belajar siwa sehingga motivasi belajar siswa yang diperoleh mengalami peningkatan.

2. Peningkatan motivasi belajar siswa pada mata pelajaran SKI di kelas V MI Plus Al Luqman Garut Setelah menggunakan model pembelajaran Learning Cycle 5e

Berdasarkan data yang diperoleh dari motivasi belajar siswa pada siklus I memperoleh hasil presentase rata-rata 64\% sehingga termasuk dalam kriteria baik, peningkatan hasil motivasi belajar siswa terlihat dalam proses pembelajaran pada siklus II. Perolehan hasil presentase rata-rata motivasi belajar siswa pada siklus II sebesar $86 \%$ sehingga termasuk kepada kriteria sangat baik, hal tersebut dapat dilihat dari siswa yang memiliki motivasi belajar sangat tinggi yaitu sebanyak 9 siswa, sedangkan siswa yang memiliki motivasi belajar tinggi sebanyak 10 siswa, hasil tersebut berdasarkan data hasil 


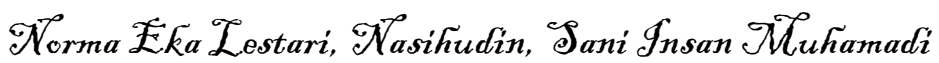

Penerapan Model Pembelajaran Learning Cycle SE untule Meninghathan Motivasi Belajar Siswa pada Mata Pelajaran Sejarah Kebudayaan Islam (SKI)

motivasi belajar siswa dari siklus I sampai siklus II setelah diterapkannya model pembelajaran Learning Cycle 5e.

Berdasarkan hasil dan proses selama penelitian, proses pembelajaran mengalami peningkatan setiap siklusnya baik dari aktivitas siswa, aktivitas guru dan motivasi belajar siswa. Hasil tersebut termasuk kedalam kategori sangat baik sehingga penelitian ini dikatakan sangat berhasil, dengan menerapkan model pembelajaran Learning Cycle 5e mampu meningkatkan motivasi belajar siswa pada mata pelajaran Sejarah Kebudayaan Islam kelas V MI Plus Al Luqman Garut.

\section{KESIMPULAN}

Berdasarkan hasil penelitian tindakan kelas dan analisis data mengenai penerapan model pembelajaran Learning Cycle 5e untuk meningkatkan motivasi belajar siswa pada mata pelajaran Sejarah Kebudayaan Islam di kelas V MI Plus Al Luqman Garut, dapat disimpulkan bahwa proses penerapan model pembelajaran Learning Cycle 5e pada mata pelajaran Sejarah Kebudayaan Islam di kelas V MI Plus Al Luqman Garut berjalan dengan baik, aktivitas guru dan siswa saat diterapkannya model pembelajaran Learning Cycle 5e mengalami peningkatan di setiap siklusnya, pada siklus I aktivitas guru memperoleh presentase sebesar $80 \%$, sedangkan pada siklus II memperoleh presentase sebesar $95 \%$. Aktivitas siswa yang diperoleh pada siklus I sebesar 76,32\% sedangkan pada siklus II memperoleh presentase sebesar $87,37 \%$. Hasil ini menunjukkan keterlaksanaan proses pembelajaran dengan penerapan model pembelajaran Learning Cycle 5e sudah memasuki kriteria "Sangat Baik", dengan demikian penerapan model pembelajaran Learning Cycle 5e dapat meningkatkan aktivitas belajar siswa.

Peningkatan motivasi belajar siswa pada mata pelajaran Sejarah Kebudayaan Islam di kelas V MI Plus Al Luqman Garut setelah menggunakan model pembelajaran Learning Cycle 5e mengalami peningkatan, pada siklus I motivasi belajar siswa memperoleh ratarata presentase sebesar 64\% termasuk kategori "Cukup". Sedangkan pada siklus II motivasi belajar siswa memperoleh rata-rata presentase $86 \%$ termasuk kategori "Sangat Baik". Hasil tersebut ditunjukkan bahwa motivasi belajar siswa kelas V MI Plus Al Luqman Garut meningkat pada mata pelajaran SKI, dengan demikian motivasi belajar siswa mengalami peningkatan dengan diterapkannya model pembelajaran Learning Cycle 5e pada mata pelajaran Sejarah Kebudayaan Islam. 
Porma Eka Lestari, Nasifiudin, Sani Insan Mutiamadi

Penerapan Model Pembelajaran Learning Cycle SE untul Meninghathan Motivasi Belajar Siswa pada Mata Pelajaran Sejarah Kebudayaan Islam (SKI)

\section{DAFTAR PUSTAKA}

Dimyati, M. (2002). Belajar dan Pembelajaran. Jakarta: Rineka Cipta.

Dwi Aprilia Astupura, H. Y. (2016). Penerapan Model Pembelajaran Learning Cycle Terhadap Motivasi dan Keterampilan Proses Sains pada Materi Pokok Cahaya. 15-27.

Mansyah, S. (2016). Manajemen Pembelajaran Sejarah Peradaban Islam. Al-Makrifat.

Purwanto, N. (2009). Prinsip-prinsip dan Teknik Evaluasi Pengajaran. Bandung: PT. Remaja Rosdakarya.

Salahudin, A. (2015). Peneliitian Tindakan kelas. Bandung: Pustaka Setia.

Salim, F. R. (2017). Pembelajaran Sejarah Kebudayaan Islam. Pontianak: IAIN Pontianak Press.

Shoimin, A. (2014). Model pembelajaran Inovatif dalam Kurikulum 2013. Yogyakarta: Ar-Ruzz Media.

Sugiyono. (2015). Metode Penelitian Pendidikan Kompetensi dan Praktiknya. Bandung: Alfabeta.

Susilawati, W. (2013). Perencanaan Pembelajaran matematika. Bandung: Insan Mandiri. 